\title{
XRN2 wt Allele
}

National Cancer Institute

\section{Source}

National Cancer Institute. XRN2 wt Allele. NCI Thesaurus. Code C94709.

Human XRN2 wild-type allele is located within 20p11.2-p11.1 and is approximately $87 \mathrm{~kb}$ in length. This allele, which encodes 5'-3' exoribonuclease 2 protein, plays a role in both the modulation RNA metabolism and stabilization of mRNA. 